\title{
Pemodelan UML untuk Sistem Informasi Persewaan Alat Pesta
}

\author{
Mia Sumiati ${ }^{1}$, Rahman Abdillah ${ }^{2}$, Alqomari Cahyo ${ }^{3}$ \\ 1,2,3Program Studi Teknik Informatika, Fakultas Teknik dan Ilmu Komputer, Universitas Indraprasta PGRI \\ 12mia270399@gmail.com, ${ }^{2}$ rabdil.bu@gmail.com*, $\underline{3 \text { alqomari.cahyo@gmail.com }}$
}

\begin{abstract}
Software design using UML modeling has been widely used among practitioners and academics. One of the advantages of using UML diagrams is flexibility and also the ability to describe the software system in more detail and specific. In this article, the author uses the SDLC method which also known as the stages of the software development cycle. The aims of this article to provide scientific contributions by giving set of recommendations in terms of designing rental information systems diagrams. The methods which has been used in this research are field studies, library research and software implementation. In the implementation stage, the author uses the Java programming language and uses MYSQL as the database. The results obtained from writing this article are in the form of software quality development, as well as in the form of recommendations for UML diagrams that can be used by software developers related to rental service businesses.
\end{abstract}

Keywords: UML, SDLC, Java, MySQL, rental service business

\begin{abstract}
Abstrak
Perancangan perangkat lunak menggunakan pemodelan UML telah banyak digunakan dikalangan praktisi dan akademisi. Salah satu kelebihan dari penggunaan diagram UML adalah fleksibilitas dan dapat menggambarkan sistem perangkat lunak lebih rinci dan detail. Dalam artikel ini, penulis menggunakan metode SDLC yang dikenal sebagai tahapan proses pengembangan perangkat lunak. Adapun penulisan artikel ini bertujuan untuk memberikan kontribusi keilmuan yang berupa rekomendasi dalam hal perancangan sistem informasi alat pesta. Adapun metode penelitian yang digunakan dalam penelitian ini adalah studi lapangan, studi pustaka dan implementasi. Dalam kaitanya dengan implementasi, penulis menggunakan bahasa pemrograman Java dan menggunakan MySQL sebagai basis data. Adapun hasil yang didapat dari penulisan artikel ini adalah berupa pengembangan kualitas perangkat lunak, serta berupa rekomendasi diagram-diagram UML yang dapat digunakan oleh pihak-pihak pengembang perangkat lunak terkait usaha jasa persewaan
\end{abstract}

Kata kunci: UML, SDLC, Java, MySQL, persewaan alat pesta.

\section{Pendahuluan}

Rekayasa perangkat lunak (Software Engineering) merupakan sebuah bidang kajian dalam bidang sistem informasi, ataupun teknik komputer. Rekayasa perangkat lunak ini berisikan tentang berbagai keilmuan dalam kaitannya dengan pengembangan perangkat lunak. Dalam jurnal ilmiah ini, penulis mendeskripsikan pengembangan perangkat lunak menggunakan pemodelan Unified Modeling Language (UML) pada studi kasus persewaan alat-alat pesta. Teknik pemodelan perangkat lunak sendiri, telah mengalami perkembangan secara terus menerus. Tujuan dari adanya pemodelan perangkat lunak adalah pengembang mampu mendeskripsikan rencana penyusunan perangkat lunak, sehingga dapat mengkomunikasikan rencana tersebut ke pihak lain, seperti: user, owner, customer ataupun kepada sesame developer program. Pemodelan yang baik adalah model diagram yang efisien dan dapat diterapkan proses pembuatan pemrogramannya pada computer [1]. Selain itu, tahap perencanaan pengembangan perangkat lunak dapat terdokumentasi dengan baik dengan adanya cetak biru (blueprint) yang menggambarkan alur, kerja, entitas dan berbagai komponen perangkat lunak yang lainnya. Adanya blueprint perangkat lunak dapat digunakan sebagai dokumentasi pengembangan perangkat lunk, serta juga dapat digunakan sebagai dokumen pelengkap pelaporan kinerja pengembangan perangkat lunak. Menurut Rumbaugh, fungsi dari adanya pemodelan perangkat lunak adalah untuk menggambarkan (visualisasi) dan secara tepat menyatakan persyaratan pengguna, sehingga seluruh stakeholders dapat memahami dan menyetujui konsep perangkat lunak. Sehingga pada akhirnya akan memudahkan dalam proses pembuatan sistem, dan dapat memodifikasi objek secara lebih detail. Pemangku kepentingan atau stakeholders adalah developer, programmer, customer atau user, owner, dan seluruh pihak yang berhubungan dengan sistem [2]. Menurut Ilin Sukma, entitas stakeholders sistem informasi penyewaan alat pesta ada tiga, yakni: Pelanggan, pemilik dan admin [3]. Adapun dalam penulisan karya ilmiah ini dilakukan pengembangan lebih lanjut berkaitan berdasarkan studi lapangan dan tinjauan pustaka yang akan dijelaskan lebih lanjut pada bagian metode penelitian.

Dalam penulisan artikel ilmiah ini, penulis menggunakan pemodelan UML dikarenakan fleksibilitas diagram-diagram pada UML yang banyak dan bervariasi. Pada UML versi 2.0 ada 14 jenis 
diagram yang dapat digunakan untuk menggambarkan alur proses pengembangan sebuah sistem. Diagramdiagram ini akan dijelaskan lebih lanjut pada bagian studi kepustakaan.

\section{Metode Penelitian}

Pada penulisan artikel ilmiah ini penulis melakukan dua jenis metode penelitian, yakni studi lapangan (field research), studi kepustakaan (library research) dan implementasi (implementation).

\subsection{Studi Lapangan (Field Research)}

Dalam kaitannya dengan studi lapangan penulis mendapatkan data dan informasi pada Nurrachmah Sarana Pesta. Nurrachmah Sarana Pesta merupakan salah satu usaha persewaan alat-alat pesta yang bertempat di daerah Kramat Jati, Jakarta Timur. Produk jasa yang disediakan berupa persewaan peralatan pesta, seperti untuk pesta pernikahan, pesta ulang tahun, pesta kelulusan siswa-siswi dan lain sebagainya. Jasa sewa yang disediakan selalu dikembangkan mengikuti perkembangan jaman dan sesuai selera masyarakat pada umumnya. Adapun visi dan misi dari Nurrachmah Sarana Pesta adalah memberikan pelayanan terbaik kepada para pelanggan dengan mengutamakan keramahan, memberikan solusi penyediaan alat-alat pesta kepada customer agar setiap acara dapat terlaksana dengan baik, serta memberikan harga dan kualitas yang terbaik.

Nurrachmah Sarana Pesta diambil sebagai lokasi penelitian karya ilmiah ini. Seperti halnya pada usaha jasa persewaan alat pesta yang lainnya, Nurrachmah Sarana Pesta memiliki beragam jenis aset dan properti yang disewakan kepada pelanggan, mulai dari peralatan elektronik, perlengkapan makan, peralatan dapur, furniture, karpet dan lain sebagainya. Adanya berbagai macam dan kategori barang yang disewa dalam suatu acara serta kurangnya pendataan yang baik bisa menyebabkan berkurangnya aset dan properti yang disewa. Berkurangnya aset ini bisa dikarenakan kelalaian staf, rusak ataupun hilang tanpa alasan. Kejadian berkurangnya aset dan properti seperti ini juga terjadi pada usaha jasa persewaan lainnya. Jika terus menerus terjadi kehilangan atau berkurangnya aset properti usaha, maka akan mengganggu siklus persewaan alat yang menyebabkan kerugian bagi pemilik usaha.

Saat karya ilmiah ini ditulis, Nurrachmah Sarana Pesta masih menggunakan pendataan aset secara manual, yaitu dengan menggunakan pendataan tulisan tangan. Adapun tujuan dari penulisan karya ilmiah ini adalah dengan adanya sistem informasi pendataan aset dan properti usaha yang lebih baik, Nurrachmah Sarana Pesta dapat meminimalisir terjadinya kehilangan, dan kerusakan barang. Pemilik akan dapat mengakses laporan yang dihasilkan dari sistem. Dalam penulisan karya ilmiah ini penulis menggunakan pemodelan diagram UML dikarenakan fleksibilitas dan ada bermacam model yang dapat digunakan untuk menggambarkan proses perangkat lunak.

\subsection{Studi Kepustakaan (Library Research)}

Dalam artikel ini, penulis melakukan kajian pustaka tentang beberapa referensi yang berhubungan dengan rekayasa perangkat lunak, yaitu tentang System Development Life Cycle (SDLC) dan Unified Modeling Language (UML). Di bawah ini merupakan penjelasan singkat tentang SDLC dan UML.

\section{SDLC (System Development Life Cycle)}

Pada bidang sistem informasi, rekayasa perangkat lunak dan sistem informasi Daur Hidup Pengembangan Sistem atau juga disebut sebagai System Development Life Cycle (SDLC) adalah sebuah siklus teknik pengembangan perangkat lunak yang terdiri dari beberapa tahap proses pengembangan sistem, yaitu: perencanaan (planning), analisis (analysis), desain (design), implementasi (implementation), evaluasi (evaluation) dan perawatan (maintenance). Ada beberapa sumber referensi lain yang menambahkan tahapan aspek pengembangan perangkat lunak dengan tahap pengujian (testing), dan dokumentasi (documentation). Konsep siklus pengembangan perangkat lunak ini berlaku untuk perangkat keras dan perangkat lunak, seperti: perangkat lunak berbasis web, berbasis android, pemrograman java, phyton, dan lain sebagainya.

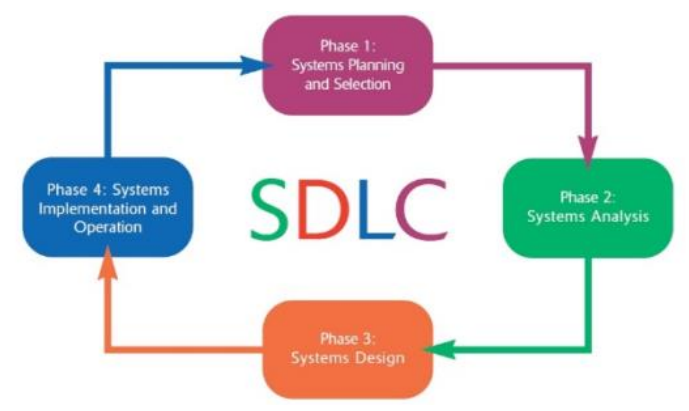

Gambar 1. System Development Life Cycle [4]

\section{UML (Unified Modeling Language)}

Unified Modeling Language (UML) adalah sebuah bahasa pemodelan perangkat lunak yang telah distandardisasi sebagai media penulisan cetak biru (blueprints) perangkat lunak (Pressman). UML bisa saja digunakan untuk visualisasi, spesifikasi, kontruksi dan dokumentasi beberapa bagian-bagian dari system yang ada dalam perangkat lunak. Dalam kata lain, seperti halnya seorang arsitek dalam membuat dokumen cetak biru yang digunakan oleh perusahaan konstruksi untuk membangun sebuah bangunan, arsitek perangkat lunak membuat diagram-diagram UML untuk membantu programmerl developer membangun perangkat lunak. Untuk selanjutnya, semakin kita mengetahui beberapa kosakata yang 
digunakan UML, kita akan semakin mudah dalam memahami spesifik.

Pada pertengahan 1990, Grady Booch, Jim Rumbaugh, dan Ivar Jacobson mengembangkan UML dengan mendapatkan masukan dari komunitas pengembang perangkat lunak [2]. Pada tahun 1997, dokumen UML 1.0 dikirimkan ke Object Management Group (OMG), sebuah lembaga konsorsium nirlaba yang terlibat dalam pemeliharaan spesifikasi untuk digunakan oleh industry komputer. Selanjutnya, UML 1.0 direvisi menjadi UML 1.1 dan diadopsi pada akhir tahun itu. Sampai dengan saat ini UML 2.3 merupakan versi terbaru dari UML dan masuk dalam salah satu standar di ISO. Seperti halnya pada bahasa pemrograman, bahasa pemodelan UML juga mengalami pembaharuan secara berkala oleh OMG. Pada UML 2.3 terdapat 14 jenis diagram yang digunakan untuk pemodelan perangkat lunak, namun pada implementasinya ada 4 jenis diagram yang sering digunakan, yakni: Use Case Diagram, Class Diagram, Activity Diagram, dan Sequence Diagram [5, 6, 7]. Pada dasarnya UML telah digunakan menjadi standar pemodelan perangkat lunak di deskripsikan desain sistem perangkat lunak melalui berbagai jenis diagram [8].

\subsection{Implementasi (Implementation)}

Implementasi dari pemodelan UML sebagai bagian dari proses perancangan perangkat lunak, penulis menggunakan bahasa pemrograman Java dan MySQL untuk menyusun basis datanya. Sedangkan software yang digunakan adalaj NetBeans. Selanjutnya, tahap implementasi akan dijelaskan lebih lanjut pada bagian Hasil dan Pembahasan.

\section{Hasil dan Pembahasan}

Penulis memfokuskan karya ilmiah ini pada aspek analisis, desain dan implementasi dalam satu bagian iterasi pada studi kasus sistem informasi persewaan alat pesta. Penulis tidak melakukan tahap evaluasi dan pengujian (testing) dikarenakan batasan masalah pada penulisan artikel ilmiah ini adalah berupa kajian pustaka dan rekomendasi pengembangan perangkat lunak bagi stakeholders. Adapun batasan penulisan penulisan artikel ini adalah memberikan kontribusi keilmuan berupa rekomendasi bagi pihak yang bermaksud untuk mengembangkan sistem informasi serupa yang menggunakan pemodelan UML.

Penulis melakukan pengembangan perangkat lunak dengan melakukan kajian pustaka dengan mengumpulkan referensi publikasi ilmiah yang berhubungan dengan sistem informasi alat pesta dan perancangan perangkat lunak yang menggunakan pemodelan UML. Penulis melakukan pencarian dengan fitur filter dan Boolean research pada laman penyedia jurnal artikel pada Google Scholar dan research gate.

\subsection{Use Case Diagram}

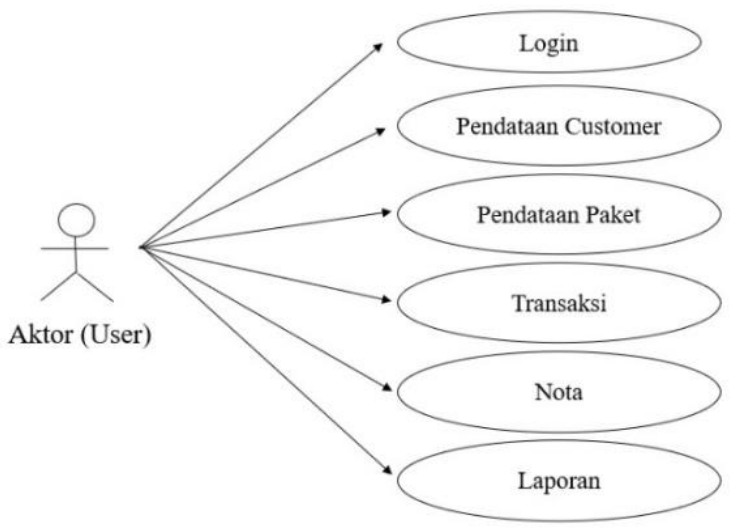

Gambar 2. Use Case Diagram

Pada gambar diatas merupakan use case diagram dari sistem informasi persewaan alat pesta. Use Case Diagram tersebut menggambarkan secara garis besar interaksi yang terjadi antara pengguna (user) dengan sistem. Aktor (user) yang terlibat dengan sistem bisa disebut sebagai admin pada tempat usaha persewaan. Admin berinteraksi dengan sistem dan dapat melakukan fitur-fitur yang tersedia pada sistem perangkat lunak. Sedangkan customer, atau owner tidak memiliki akses terhadap sistem perangkat lunak, namun admin nantinya akan memberikan laporan sebagai output dari sistem perangkat lunak. Pada karya ilmiah ini juga mengadopsi dan mengembangkan karya ilmiah yang telah dilakukan oleh beberapa penulis tentang sistem informasi penyewaan alat pesta menggunakan pemodelan UML $[3,9]$.

\subsection{Activity Diagram}

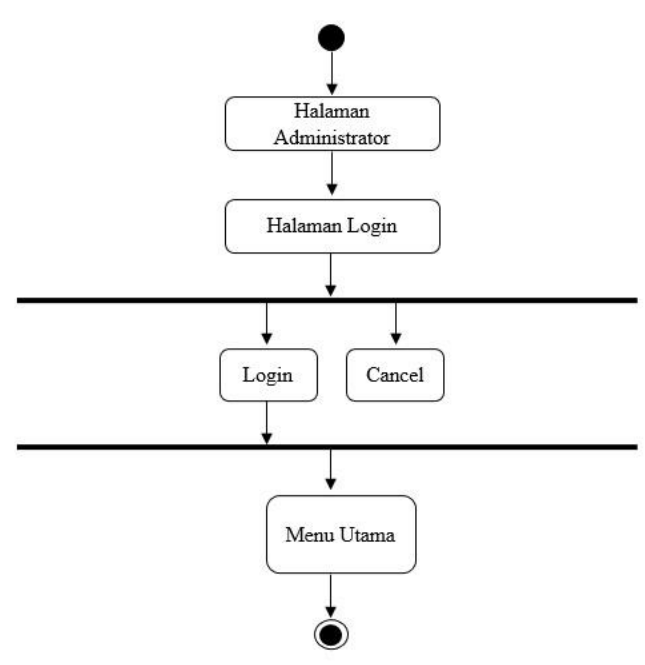

Gambar 3. Activity Diagram Login 


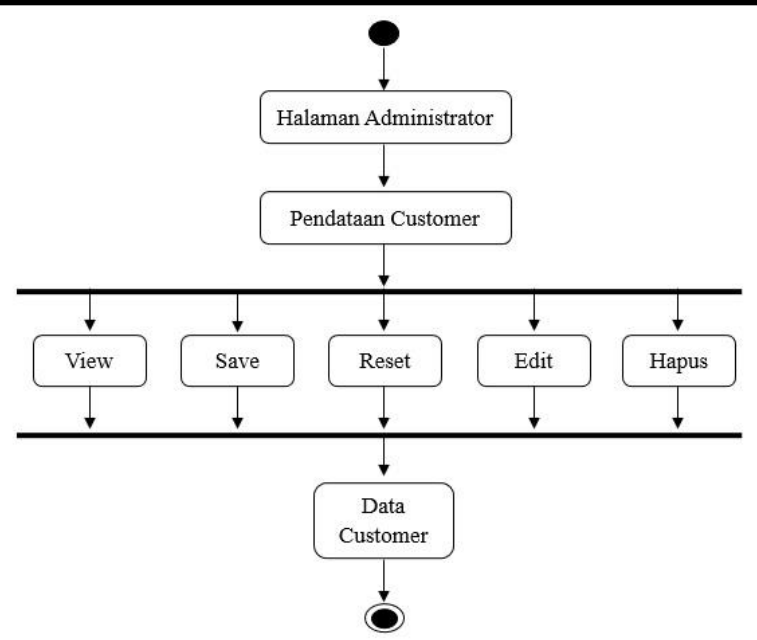

Gambar 4. Activity Diagram Pendataan Customer

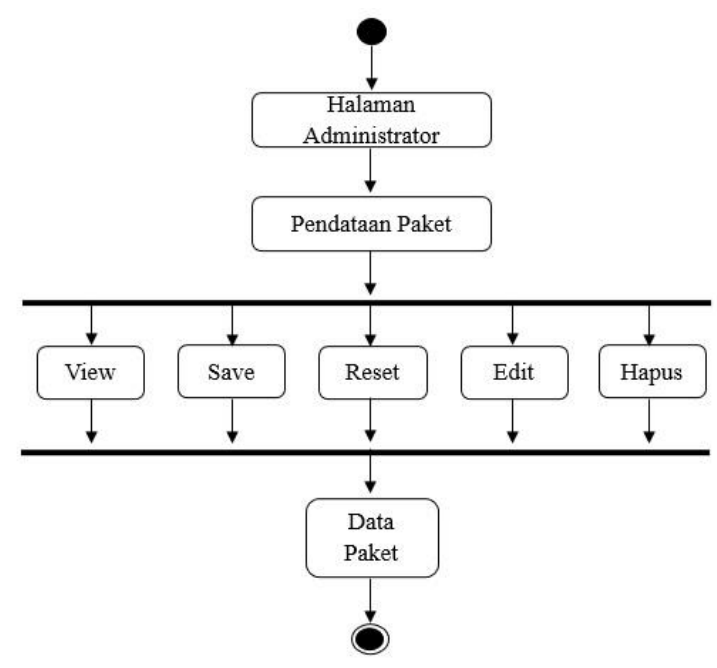

Gambar 5. Activity Diagram Pendataan Paket Sewa

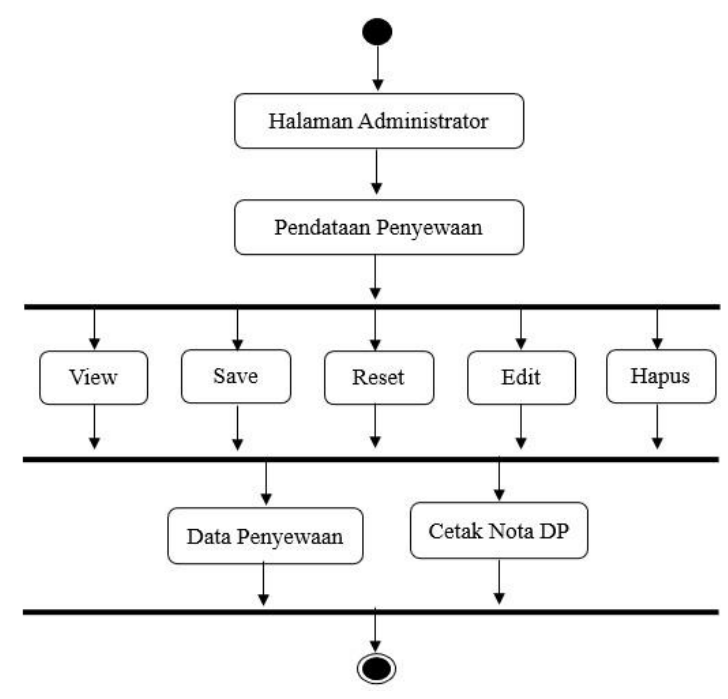

Gambar 6. Activity Diagram Penyewaan

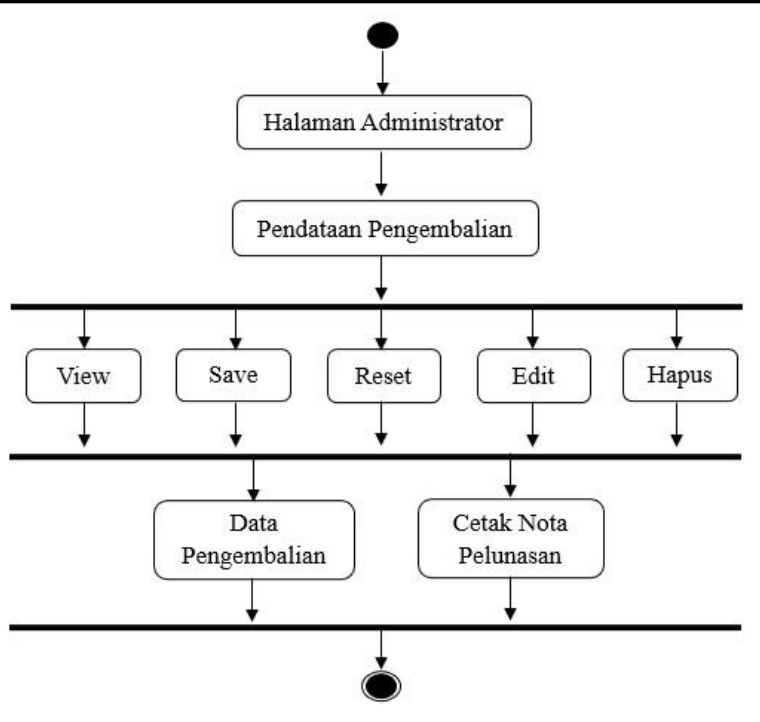

Gambar 7. Activity Diagram Pengembalian

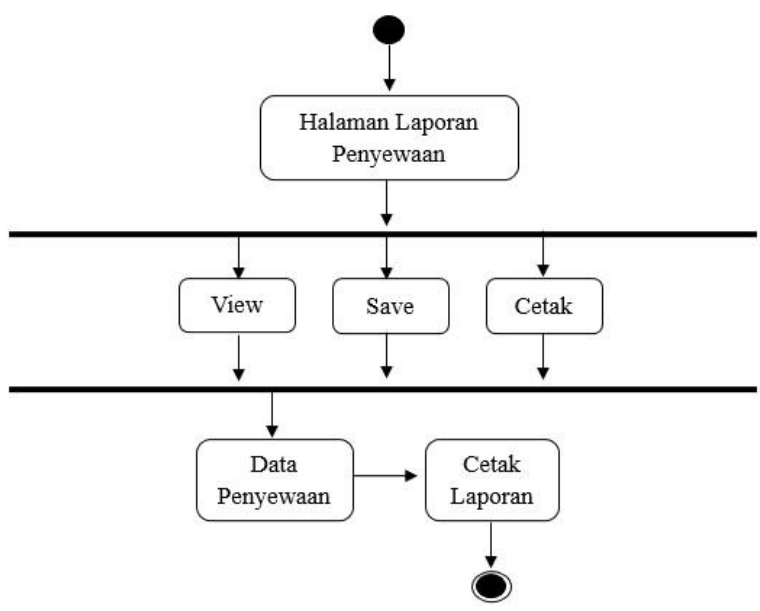

Gambar 8. Activity Diagram Laporan

Dapat kita lihat pada gambar 3, 4, 5, 6, 7 dan 8 merupakan gambar activity diagram untuk masingmasing fitur yang dapat dilakukan oleh sistem perangkat lunak. Activity diagram tersebut menjelaskan tentang alur proses yang bisa dilakukan oleh sistem secara per sub bagian (objek). Selanjutnya, diagram-diagram tersebut menjelaskan setiap fitur objek yang akan digunakan pada bahasa pemrograman Java. Objek-objek ini nantinya saling terhubung satu sama lain dengan koneksi pada database. Untuk lebih jelasnya tentang koneksifitas basis data, dapat dilihat pada bagian class diagram.

\subsection{Sequence Diagram}

Sequence diagram merupakan salah satu jenis diagram pada UML yang dapat menjelaskan urutan waktu pemrosesan sistem. Pada gambar-gambar dibawah ini, penulis mendeskripsikan urutan sistem per bagian objek. 


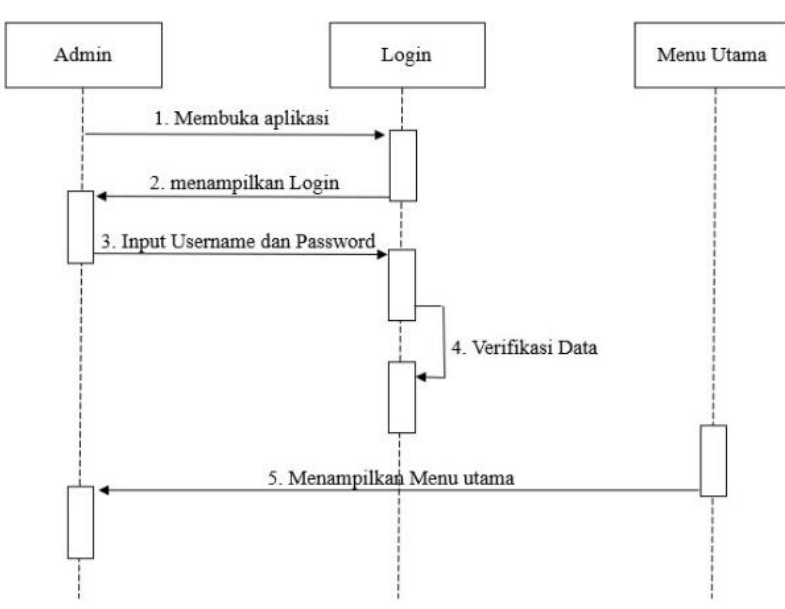

Gambar 9. Sequence Diagram Login

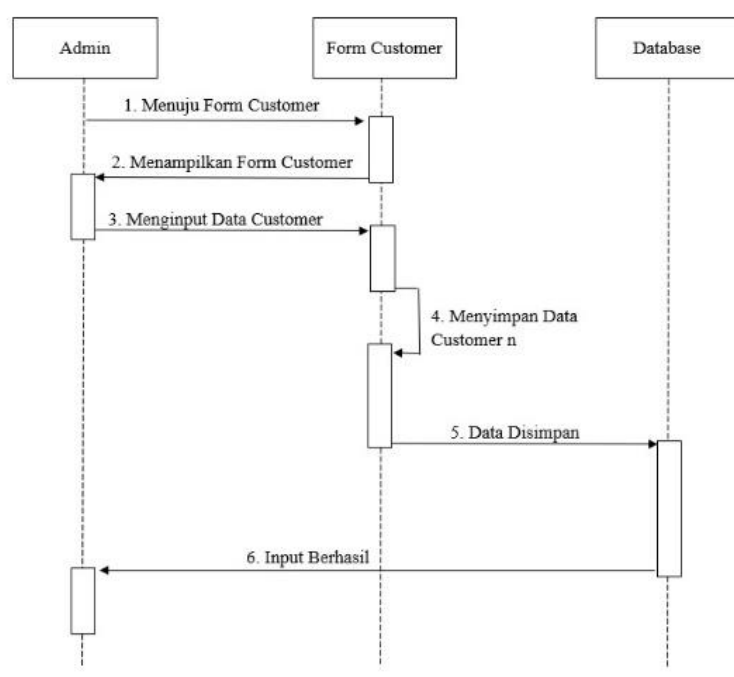

Gambar 10. Sequence Diagram Pendataan Customer

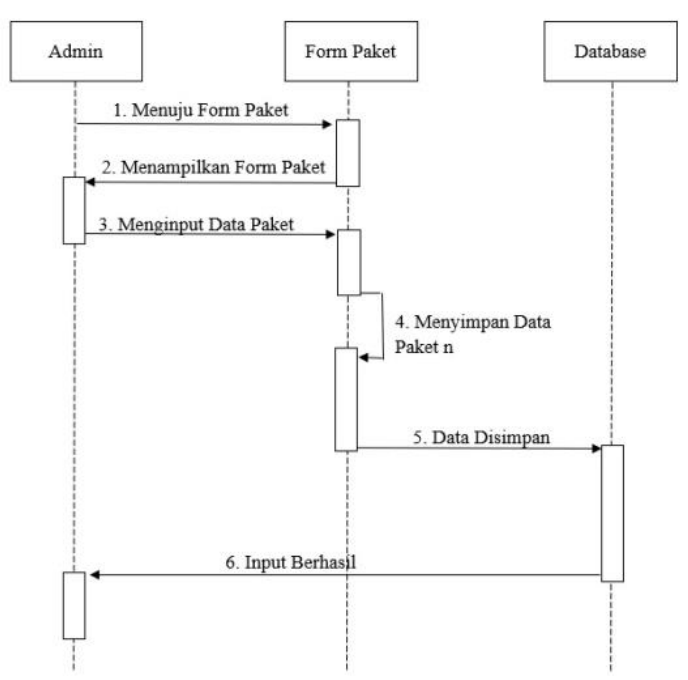

Gambar 11. Sequence Diagram Pendataan Paket Sewa

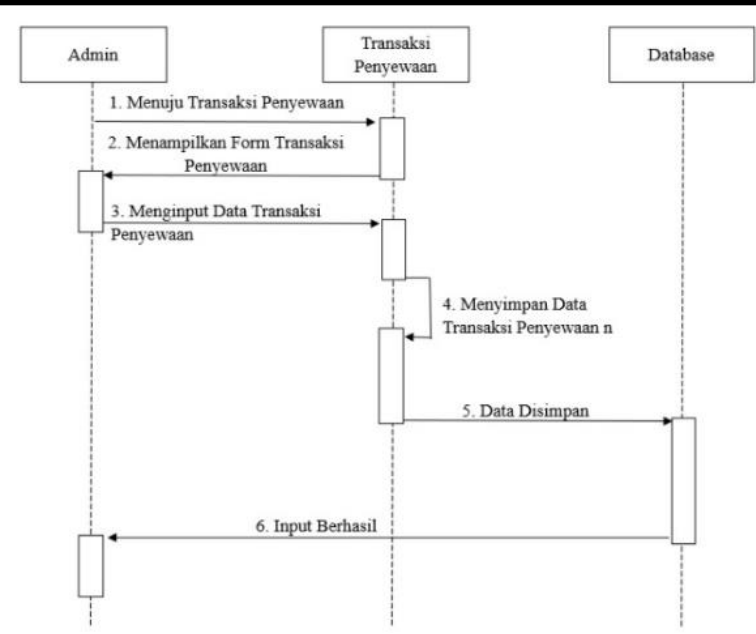

Gambar 12. Sequence Diagram Transaksi

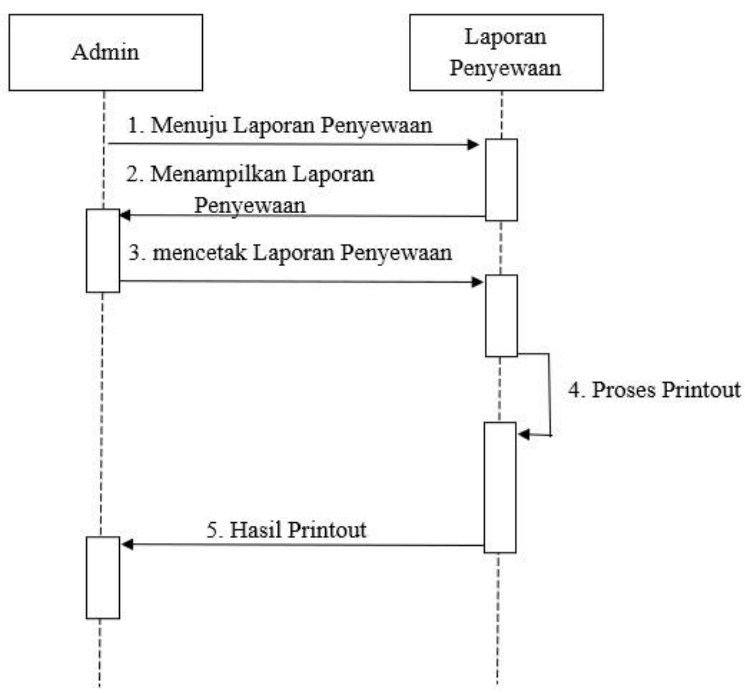

Gambar 13. Sequence Diagram Laporan

Sequence Diagram yang terdapat pada gambar 9, 10, 11, 12, dan 13 dapat menjelaskan secara lebih rinci tentang alur proses per bagian objek. Urutan proses yang detail dibutuhkan guna mendukung kinerja perangkat lunak menjadi lebih teratur.

\subsection{Class Diagram}

Class Diagram merupakan salah satu jenis diagram UML yang digunakan untuk menggambarkan koneksifitas basis data. Pada gambar dibawah ini bisa kita lihat ada 5 database yang digunakan pada sistem informasi alat pesta, yakni: customer, paket, sewa, pengembalian dan laporan. 


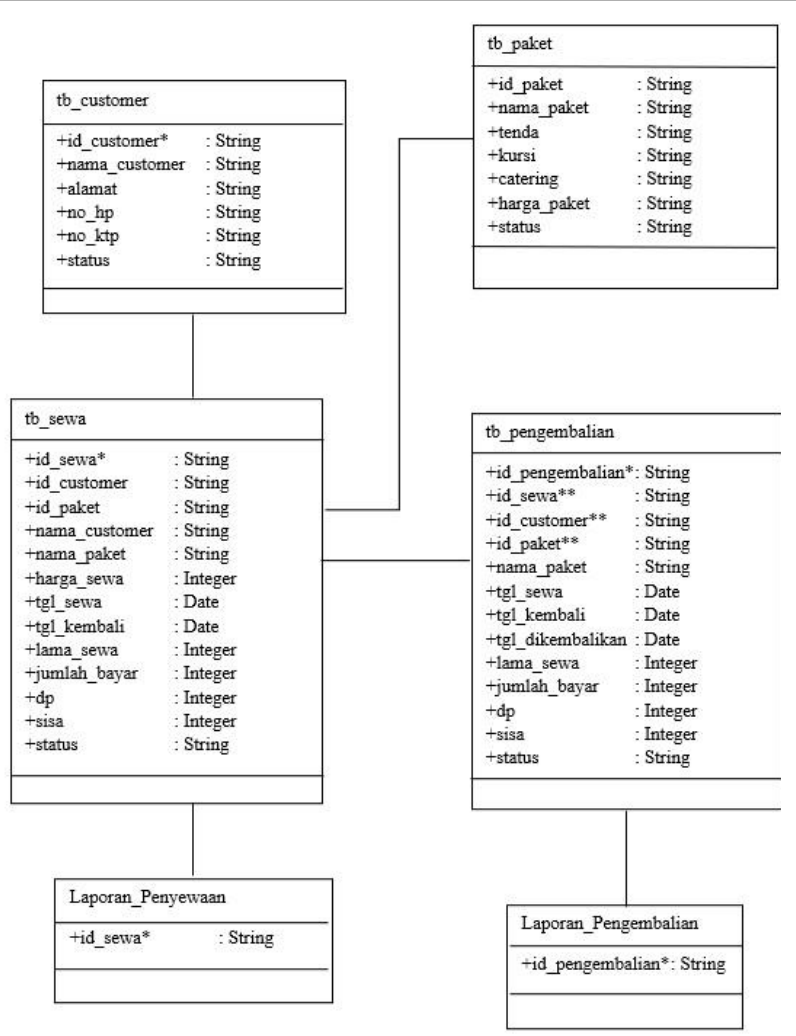

Gambar 14. Class Diagram Sistem Informasi Persewaan Alat Pesta

\subsection{Implementasi Perangkat Lunak}

Pada tahap selanjutnya dari artikel ilmiah ini, penulis melakukan pemrograman menggunakan Bahasa pemrograman Java pada software Netbeans dengan database MySQL. Berdasarkan diagram-diagram UML yang telah disusun sebelumnya, dapat kita lihat dibawah ini merupakan beberapa tampilan layar sistem informasi persewaan alat pesta.

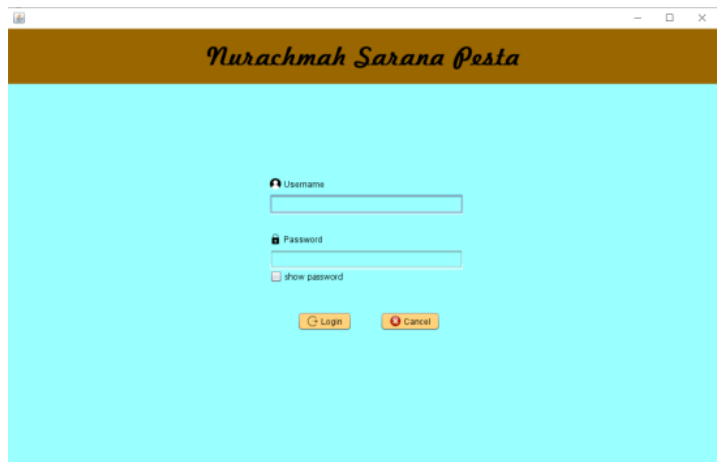

Gambar 15. Form Login

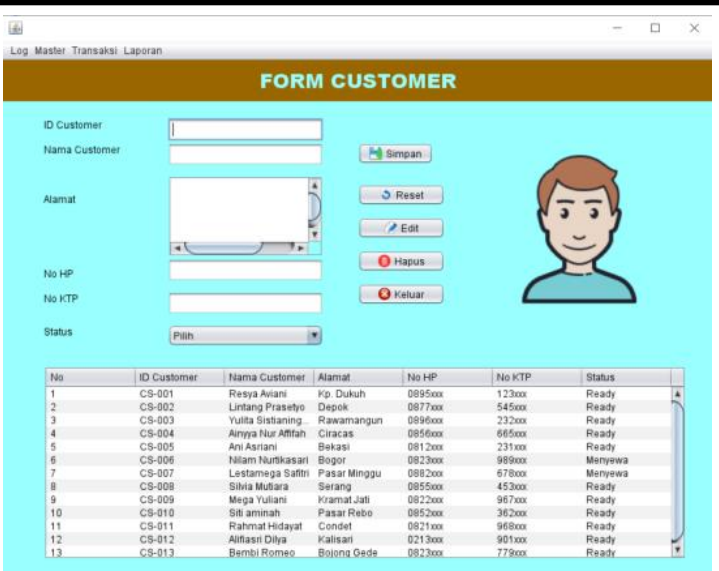

Gambar 16. Tampilan Layar Form Customer

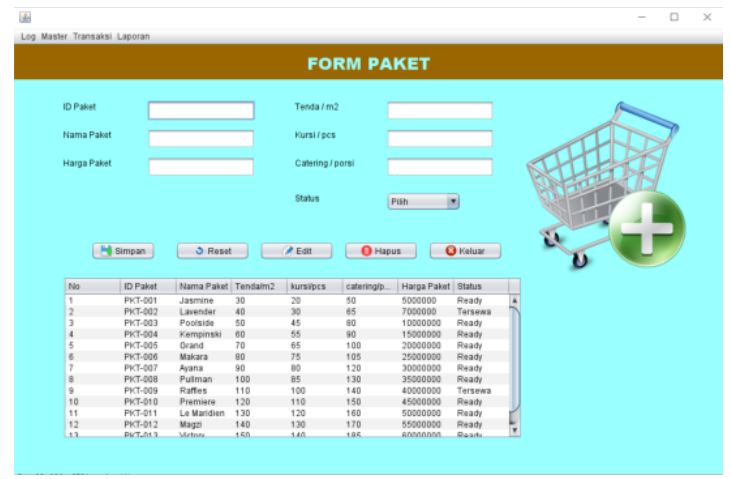

Gambar 17. Tampilan Layar Form Paket

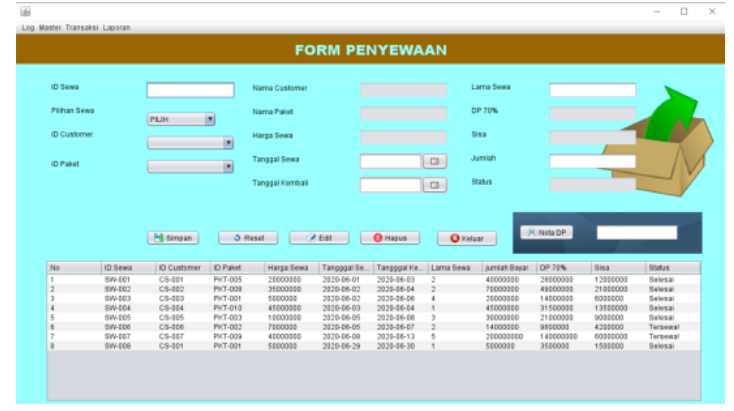

Gambar 18. Tampilan Layar Form Penyewaan

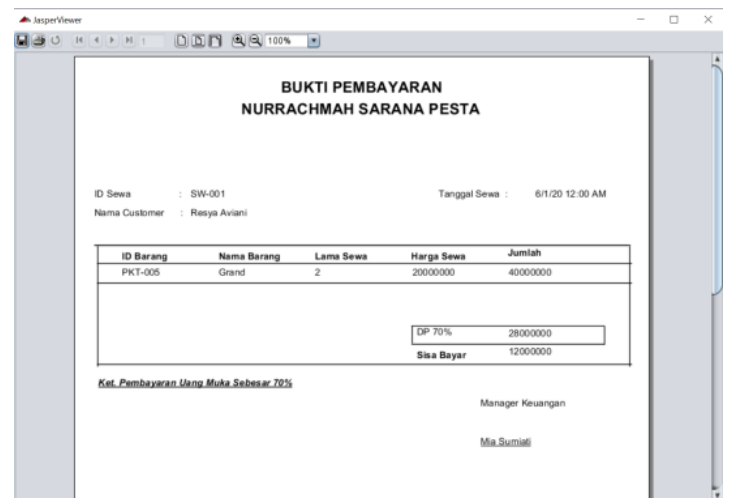

Gambar 19. Tampilan Layar Bukti Transaksi 


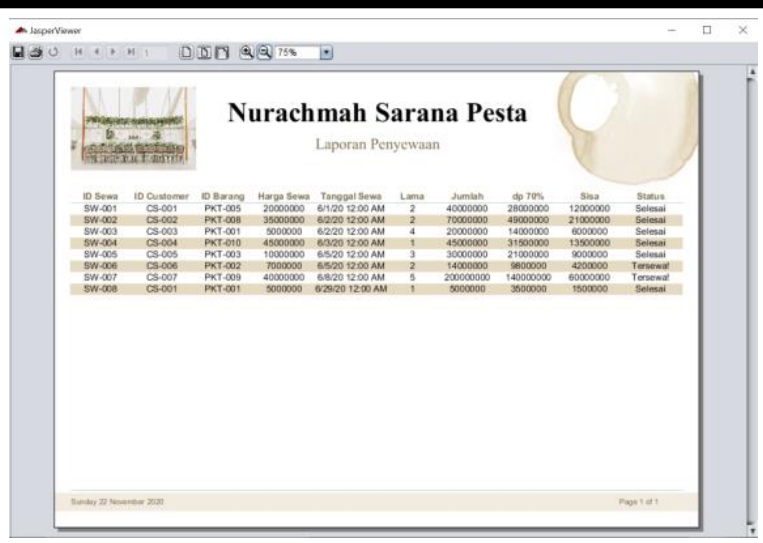

Gambar 20. Tampilan Layar Laporan (e-report)

Pada gambar diatas, gambar 15, 16, 17, merupakan gambar tampilan layar form login, form pendataan customer, form pendataan paket dan form penyewaan, sedangkan pada gambar 19 dan 20 dapat kita lihat tampilan layar transaksi dan tampilan layar untuk fitur cetak laporan dalam bentuk pdf.

\subsection{Evaluasi}

Tahap Evaluasi merupakan tahap terakhir yang perlu diimplementasikan dari keseluruhan tahapan siklus pengembangan sistem SDLC. Pada artikel ilmiah ini penulis melakukan evaluasi perancangan perangkat lunak dengan tiga aspek parameter dari usability testing, yakni: efficiency (efisiensi), effectiveness (efektifitas) dan satisfaction (kepuasan) [10]. Dalam karya ilmiah ini mengadopsi kuisioner yang terdapat pada SUMI (Software Usability Measurement Inventory) $[11,12]$. Tujuan dari adanya kuisioner ini adalah untuk mengetahui dan mengukur sejauh mana perangkat lunak dapat digunakan dengan baik.

Kuesioner diberikan kepada beberapa user (pengguna) yang terdapat pada Nurrachmah Sarana Pesta, termasuk pemilik, staf manajemen operasional, dan beberapa karyawan dengan total 10 responden, dengan sebaran responden 7 pria dan 3 wanita. Responden diminta untuk menggunakan perangkat lunak yang telah terinstall pada komputer yang telah tersedia di kantor manajemen Nurrachmah. Adapun spesifikasi komputer yang digunakan untuk pengujian perangkat lunak adalah sebagai berikut: Dell Desktop Intel(R) Core (TM) i5-4590 CPU @3.30 GHz. OS: Windows 10 Pro, 64 bit. Memory (RAM): 12 GB. Hardisk: 1 TB dengan koneksi internet LAN.

Dalam melakukan pengujian sistem informasi persewaan alat pesta, ada lima tahap yang harus dilakukan oleh masing-masing responden, yakni:

Tugas 1: Melakukan Login kedalam sistem sebagai user (pengguna), diawali dengan mengetikkan username dan password
Tugas 2: Menambahkan dan mengubah data pada Form Customer, Form Paket dan Form Penyewaan

Tugas 3: Menampilkan data yang telah diisikan pada Form Customer, Form Paket dan Form Penyewaan

Tugas 4: Menampilkan laporan pada layar computer dengan menunjukkan tanggal dan waktu cetak laporan

Tugas 5: Menyimpan file laporan dalam bentuk pdf dan mengakses file tersebut tanpa menggunakan perangkat lunak sistem (mengakses file pada folder Windows)

Penulis menyusun survey kuesioner dengan mengintegrasikan metode SUMI dengan jumlah 10 pertanyaan dan telah mengindikasikan aspek-aspek efisiensi, efektifitas dan kepuasan. Terdapat 4 kriteria jawaban pada kuisioner, yaitu: Tidak Tahu $(\mathrm{TT}=1)$, Kurang Setuju $(K=1)$, Cukup $(C=2)$, Setuju $(S=3)$, Sangat Baik $(\mathrm{SB}=4)$. Dari 10 pertanyaan tersebut adapun hasil kuisioner yang telah dikumpulkan adalah sebagai berikut:

Tabel 1. Rekapitulasi Hasil Kuisioner

\begin{tabular}{cccc}
\hline \multirow{2}{*}{ User } & \multicolumn{3}{c}{ Penilaian } \\
\cline { 2 - 4 } & Skor & Maks & $\%$ \\
\hline 1 & 35 & 40 & 87.5 \\
\hline 2 & 29 & 40 & 72.5 \\
\hline 3 & 29 & 40 & 72.5 \\
\hline 4 & 34 & 40 & 85 \\
\hline 5 & 28 & 40 & 70 \\
\hline 6 & 28 & 40 & 70 \\
\hline 7 & 29 & 40 & 72.5 \\
\hline 8 & 36 & 40 & 90 \\
\hline 9 & 26 & 40 & 65 \\
\hline 10 & 29 & 40 & 72.5 \\
\hline Total & 299 & 400 & 75.75 \\
\hline
\end{tabular}

Pengujian sistem informasi persewaan alat pesta dilakukan dengan metode Black Box Testing, yakni tidak ada responden yang mengetahui algoritma atau alur pemrograman didalam sistem. Berdasarkan datadata yang dihimpun dari kuisioner didapat nilai keseluruhan sebesar 75.75 (dalam persentase). Sedangkan data yang dihimpun dari kuesioner untuk nilai efisiensi sebesar 60 dan kepuasan sebesar 63 .

\section{Kesimpulan}

Berdasarkan hasil rancangan perangkat lunak diatas penulis telah melakukan perancangan perangkat lunak sistem informasi persewaan alat pesta dengan mengikuti tahapan perancangan metode System Development Life Cycle (SDLC) dan pemodelan dengan menggunakan Unified Modeling Language (UML). Dari hasil rancangan diatas didapat beberapa tahapan implementasi perancangan perangkat lunak yang dapat dijadikan rujukan dan rekomendasi bagi stakeholders ataupun akademisi yang melakukan penelitian serupa. Adapun rekomendasi perancangan 
perangkat lunak sistem informasi persewaan alat pesta, berupa diagram-diagram UML, seperti Use Case Diagram, Activity Diagram, Sequence Diagram dan Class Diagram. Tujuan dari penulisan diagramdiagram ini adalah untuk mengkomunikasikan rancangan-rancangan desain perangkat lunak kepada para pemangku kepentingan (stakeholders), yakni: pemilik usaha (owner), programmer, perancang database, pengguna (user), admin, dan lain sebagainya.

Berdasarkan hasil evaluasi yang dilakukan penulis, sistem informasi persewaan alat pesta ini masih dapat dikategorikan cukup efektif dalam penggunaanya, namun juga ada beberapa aspek yang masih memerlukan pengembangan lebih lanjut khususnya pada aspek efisiensi dan kelayakan. Di sisi lain, perancangan sistem informasi ini belum melibatkan pemikiran dari praktisi yang cukup berpengalaman dalam hal sistem informasi persewaan alat, sehingga saran dari penulis untuk mengembangkan sistem informasi ini perlu pertimbangan dari pakar atau praktisi berpengalaman, khususnya pada tahap evaluasi pengujian perangkat lunak dengan menggunakan metode White Box Testing.

\section{Daftar Rujukan}

[1] Sutejo, S. (2016). Pemodelan UML Sistem Informasi Geografis Pasar Tradisional Kota Pekanbaru. Digital Zone: Jurnal Teknologi Informasi Dan Komunikasi, 7(2), 89-99.

[2] Rumbaugh, J., Jacobson, I., \& Booch, G. (2005). The Unified Modeling Language Reference Manual $2^{\text {nd }}$ Edition. Boston: Addison-Wesley

[3] Sukma, I., N.A.A, A., \& Henny. (2020). Sistem Informasi Penyewaan Alat dan Dekorasi Pesta Pada CV. Vira Salon Berbasis Website. Simkom, 5(1), 1-15.

[4] Valacich, J. S., George, J. F., \& Hoffer, J. A. (2012). Essentials of Systems Analysis and Design $5^{\text {th }}$ edition. NewJersey:Pearson.

[5] Syafitri, Y. (2016). Pemodelan Perangkat Lunak Berbasis UML Untuk Pengembangan Sistem Pemasaran Akbar Entertainment Natar Lampung Selatan. Cendikia, 12(1), 32-33.

[6] Suendri. (2018). Implementasi Diagram UML (Unified Modelling Language) Pada Perancangan Sistem Informasi Remunerasi Dosen Dengan Database Oracle (Studi Kasus: UIN Sumatera Utara Medan). Jurnal Ilmu Komputer Dan Informatika, 3(1), 1-9.

[7] Saepudin, S. L., \& Dhaniawaty, R. P. (2019). Sistem Informasi Penyewaan Mobil Berbasis Web Pada Pt . Frasindo Lima Mandiri Information System of Rent Cars Web-Based on Pt . Frasindo Lima Mandiri. Jurnal Manajemen Informatika (JAMIKA), 49.

[8] Raghuraman, A., Ho-Quang, T., Chaudron, M. R. V., Serebrenik, A., \& Vasilescu, B. (2019). Does UML modeling associate with lower defect proneness?: A preliminary empirical investigation. IEEE International Working Conference on Mining Software Repositories, 2019-May, 101-104.

[9] Ekosari, D. W. (2013). Sistem Informasi Persewaan Alat Pesta Berbasis Web pada CV. Tri Manunggal di Ungaran. Sistem Informasi, 13.

[10] Wasis Haryono. (2019). Usability Engineering and Evaluation of Usability In District Tourism And Culture Information Systems. Data Science: Journal of Computing and Applied Informatics, 3(2), 101-109.

[11] Khairunisa, Y., Tyas, S. S., Purwanto, A. (2020). Software Usability Measurement Inventory for Student Information Academic System at Politeknik Negeri Media Kreatif. ... (International Journal of Information System \& Technology, 4(36), 559-565.
[12] Kirakowski, J., \& Corbett, M. (1993). SUMI: the Software Usability Measurement Inventory. British Journal of Educational Technology, 24(3), 210-212. 